NUSANTARA : Jurnal Ilmu Pengetahuan Sosial - Vol. 6 No 1 (2019) ( Januari - Juni )

issn online : 2550-0813 issn cetak : 2541-657X

http://jurnal.um-tapsel.ac.id/index.php/nusantara

\title{
PERBANDINGAN MODEL PEMBELAJARAN KREATIF DAN \\ PEMBELAJARAN PRODUKTIF TERHADAP MINAT BELAJAR PPKNPESERTA DIDIK DI KELAS X SMA NEGERI 1 ULU \\ BARUMUN TAHUN PELAJARAN 2016 - 2017
}

Ahmad Husein Nasution, Ali Nurdin Siregar

ahmad.husein@um-tapsel.ac.id

FKIP Universitas Muhammadiyah Tapanuli Selatan

\begin{abstract}
Abstrak
Rumusan masalah dalam penelitian ini adalah Apakah ada perbandingan model pembelajaran kreatif dengan model pembelajaran produktifterhadap minat belajar PPKn peserta didik di kelas X SMA Negeri 1Ulu Barumun Tahun Pelajaran 2016-2017“?

Dengan rumus yang dipergunakan untuk menguji hipotesis dimaksud adalah rumus "t-test polled varians."

Dari perhitungan t-test polled varians tersebut maka t-hitungnya adalah 6,667 dengan melihat daftar t-tabel dengan jumlah sampel 60 kemudian digunakan derajat kebebasan $(\mathrm{dk})=\mathrm{n}_{1}+\mathrm{n}_{2}-2$ dan taraf kesalahan 5\% adalah Sesuai dengan ketentuan jika $t_{\text {hitung }}>t_{\text {tabel }}$ dengan kata lain $(6,667<2000)$ maka hipotesis altematif (Ho) dapat diterima. Dari perhitungan di atas, maka hipotesis alternatif (Ho) menyatakan: “Ada perbandingan model pembelajaran kreatif dengan model pembelajaran produktif terhadap minat belajar PPKnpeserta didik di kelas X SMA Negeri 1Ulu Barumun Tahun Pelajaran 2016-2017“?

Setelah dilakukan pengujian hipotesis diperoleh $t_{\text {hitung }} 6,667$ sedangkan nilai $t_{\text {tabel }}=2000$, ini menunjukkan $t_{\text {hitung }}>t_{\text {tabel }}$, artinya ada perbandingan model pembelajaran kreatif dengan model pembelajaran produktif terhadap minat belajar PPKnSehingga penulis berasumsi bahwa dengan melakukan berbagai model pembelajaran akan menunjukkan suatu minat belajar dan prestasi belajar peserta didik dalam menerima proses.
\end{abstract}

KataKunci :Model Pembelajaran Kreatif Dengan Model Pembelajaran ProduktifTerhadap Minat Belajar PPKn 
NUSANTARA : Jurnal Ilmu Pengetahuan Sosial - Vol. 6 No 1 (2019) ( Januari - Juni )

issn online : $2550-0813$ issn cetak : $2541-657 \mathrm{X}$

http://jurnal.um-tapsel.ac.id/index.php/nusantara

\section{Pendahuluan}

Pendidikan adalah suatu usaha yang dengan sengaja dipilih untuk mempengaruhi dan membantu anak yang bertujuan untuk meningkatkan ilmu pengetahuan, jasmani dan akhlak sehingga secara perlahan bisa mengantarkan anak kepada tujuan dan cita-citanya yang paling tinggi. Agar memperoleh kehidupan yang bahagia (berkemakmuran dari segi financial) dan apa yang dilakukannya dapat bermanfaat bagi dirinya sendiri, keluarganya, masyarakatnya sampai bagi bangsa dan negara termasuk bagi agamanya.

Pendidikan dapat diperoleh baik secara formal dan non formal. Pendidikan secara formal diperoleh dengan mengikuti program-program yang telah direncanakan, terstruktur oleh suatu institusi, departemen atau kementerian pendidikan dalam suatu negara. Sedangkan pendidikan non formal adalah pengetahuan yang diperoleh dari kehidupan sehari-hari dalam bermasyarakat mulai dari adanya pengalaman baik dan buruk yang dialaminya sendiri maupun yang diajarkan oleh orang lain yang dianggap menjadi seorang panutan, teladan dan lain sebagainya.

Dengan demikian pendidikan ini sangat dibutuhkan dan menduduki posisi penting untuk menuju perkembangan dan kemajuan suatu bangsa yang berkemajuan Sehingga tujuan pendidikan nasional di atas akan dapat tercapai apabila ada tanggungjawab dari semua pihak tidak terkecuali bagi penyelenggara pendidikan maupun yang menjadi peserta dari kependidikan itu. Apakah sebagai peserta didik, orang tua, guru, pemerintah, lembaga pendidikan (sekolah) serta masyarakat, sehingga pendidikan bukan hanya tanggung jawab dari salah satu pihak saja melainkan semua pihak juga harus terlibat.

$$
\text { Selanjutnya pembelajaran }
$$
yang akan dilalui pada lembaga pendidikan yang diselenggarakan oleh pemerintah maupun swasta pada prinsipnya memiliki tujuan yang sama yaitu untuk mencerdaskan kehidupan bangsa, oleh karena itu sudah merupakan hal yang wajar ketika proses yang akan dilakukan oleh guru dengan peserta didik didalam pembelajarannya adalah bagaimana agar materi pembelajaran yang akan disampaikan oleh guru dapat dengan mudah diterima oleh peserta didik. Belajar dari pengalaman yang telah dilalui oleh guru, didalam proses pembelajaran yang akan dilaksanakan itu tidak dapat dikatakan selalu konstan (tetap), apalagi masalah prestasi, bahkan motivasi, minat yang dimiliki oleh peserta didik selalu mengalami perubahan, sesuai dengan perubahan kondisi perkembangan globalisasi yang ada. Kenyataan yang dihadapi seperti ini merupakan usaha yang harus dijalankan oleh guru, oleh karena itu untuk peningkatan minat belajar peserta didik tetap memerlukan 
NUSANTARA : Jurnal Ilmu Pengetahuan Sosial - Vol. 6 No 1 (2019) ( Januari - Juni )

issn online : $2550-0813$ issn cetak : $2541-657 \mathrm{X}$

http://jurnal.um-tapsel.ac.id/index.php/nusantara

model pembelajaran yang lebih mudah diterima oleh peserta didik jika selama ini pembelajaran yang dibuat oleh guru bidang studi lebih condong dan sering menggunakan pembelajaran yang konvensional seperti dengan monotonnya dengan ceramah dan lain sebagainya mengakibatkan peserta didik lebih banyak yang tidak menunjukkan keaktifannya. Pembelajaran Kreatif dan

pembelajaran produktif adalah model pembelajaran yang perlu untuk dikembangkan dalam suatu proses pembelajaran sekaligus untuk dapat mengembangkan kemampuan atau pun potensi yang ada dalam diri peserta didik secara terarah sehingga bisa menghasilkan peserta didik yang cerdas, terampil serta bisa memperoleh prestasi yang maksimal.

Peningkatan

mutu pembelajaran ditentukan oleh kedua belah pihak, kesiapan sumber daya manusia yang terlibat dalam proses pendidikan seperti guru dan peserta didik adalah dua faktor penting yang tidak bisa dipisahkan dalam pembelajaran. Kedua komponen ini saling ketergantungan dan mempengaruhi tingkat keberhasilan pembelajaran. Guru termasuk sebagai kunci keberhasilan peserta didik dalam pembelajaran , bagaimanabesarnyapun kemampuan seorang guru dalam mengelola kelas, yang namanya model pembelajaran yang akan diterapkan tetap menjadi satu bagian yang tidak terpisahkan dengan pengelolaan kelas.
Dalam pembelajaran yang dilaksanakan pada saat observasi, penulis juga termasuk mengalami kesulitan dalam menghadapi kondisi kesiapan peserta didik untuk mengikuti latihan yang diselenggarakan oleh penulis, hal ini dapat dilihat dari hasil yang diperoleh peserta didik masih sangat rendah yaitu rata- rata 70 , sedangkan target yang ditentukan adalah 7,5 Untuk meningkatkan minat belajar peserta didik penulis berencana membuat model pembelajaran kreatif dan akan dibandingkan dengan pembelajaran produktif, sekaligus untuk usaha menarik minat pesertadidik dalam meningkatkan pencapaian hasil yang maksimal dari proses sebelumnya. Guru dalam mempraktekkan pembelajaran kreatif salah satunya adalah untuk adanya efektivitas pembelajaran seperti model Bentukan Pasangan dimana guru nantinya akan menunjuk pasangan peserta didik yang satu dengan peserta didik lainnya dalam menjalankan tugas. Keterlibatan peserta didik secara intelektual dan emosional dalam pembelajaran peseta didik di dorong untuk menemukan/mengkonstruksi sendiri konsep yang sedang dikaji melalui penafsiran yang dilakukan dengan berbagai cara seperti observasi/diskusi atau percobaan.

Proses pembelajaran ini melibatkan peran guru dalam pembelajaran dan keterlibatan peserta didik sebagai obyek dan juga subjek pembelajaran. Salah satu komponen 
NUSANTARA : Jurnal Ilmu Pengetahuan Sosial - Vol. 6 No 1 (2019) ( Januari - Juni )

issn online : $2550-0813$ issn cetak : $2541-657 \mathrm{X}$

http://jurnal.um-tapsel.ac.id/index.php/nusantara

berhasil atau tidaknya proses belajar mengajar ditentukan dengan minat belajar.

Model pembelajaran kreatif adalah proses pembelajaran yang mengharuskan guru dapat memotivasi dan memunculkan kreativitas peserta didik selama proses pembelajaran berlangsung, dengan menggunakan beberapa metode dan strategi yang variatif, misalnya kerja kelompok, pemecahan masalah dan sebagainya. Pembelajaran kreatif mengharuskan guru untuk mampu merangsang peserta didik memunculkan kreativitas, baik dalam konteks kreatif berpikir maupun dalam konteks kreatif melakukan sesuatu.

Produktif adalah suatu kegiatan yang menghasilkan sesuatu, berupa hal baru yang didapat dari membaca, benda, tulisan, dan hal yang baik lainnya.

Menurut Djaali minat itu dapat : “ Diekspresikan melalui pernyataan yang menunjukan bahwa peserta didik lebih menyukai suatu hal daripada hal lainnya, dapat pula dimanifestasikan melalui partisipasi dalam suatu aktivitas." 1 Minat itu memang tidak di bawa sejak lahir, melainkan diperoleh kemudian setelah adanya interaksi atau proses yang dilaksanakan oleh pengarah, pembimbing, pengajar bahkan tenaga pendidik itu sendiri.

\footnotetext{
${ }^{1}$ Djaali, Ensiklopedi Pendidikan, Jakarta :
} Gramedia.2013 hal. 121
Minat belajar adalah sebagai suatu rasa lebih suka dan rasa keterkaitan pada sesuatu hal aktivitas tanpa ada yang menyuruh untuk melaksanakannya. Minat pada dasarnya adalah penerimaan akan suatu hubungan antara diri sendiri dengan diluar diri.

Setelah Peneliti melaksanakan observasi proses belajar mengajar di kelas X SMA Negeri 1 Ulu Barumun terlihat dari sikap atau minat belajar peserta didik masih kurang selama proses pembelajaran berlangsung, seperti peserta didik kurang menunjukkan perhatian penuh selama proses pembelajaran. Keadaan ini mengakibatkan hasil belajar ekonomi peserta didik kurang maksimal.

\section{Pengertian Model Pembelajaran} Kreatif dan Produktif

Pengertian model pembelajaran menurut Kamus Bahasa Indonesia adalah : “ pembelajaran yang tergambar dari awal sampai akhir yang di sajikan secara khas oleh guru dengan kata lain model pembelajaran merupakan bungkus atau bungkai dari penerapan suatu pendekatan sedangka Anni mengatakan : “ Model juga dapat dikatakan sebagai penambah pengalaman." 2 Pengalaman yang dimaksud adalah seperti dalam teori belajar persepsi yang dikembangkan oleh Arthur Comb dalam Sutarto,dkk menyatakan bahwa : “ Model dapat dipengaruhi oleh cara - cara individu

${ }^{2}$.Anni,Psikologi Belajar, Semarang,UPT UNNES,Press,2007,hal. 25. 


\section{NUSANTARA : Jurnal Ilmu Pengetahuan Sosial - Vol. 6 No 1 (2019) ( Januari - Juni ) issn online : $2550-0813$ issn cetak : $2541-657 \mathrm{X}$ http://jurnal.um-tapsel.ac.id/index.php/nusantara}

dalam menerima dirinya sendiri dalam lingkungannya." ${ }^{3}$ Selanjutnya, masih dalam pengertian belajar oleh Morris L. Bigge yang dikutip oleh Darsono,dkk, Seterusnya James Wittaker masih dalam Darsono,dkk, belajar itu juga bisa dikatakan bahwa : " belajar itu adalah Proses yang menimbulkan atau merubah perilaku latihan atau pengalaman." ${ }^{4}$ Jadi metode itu dapat diaktakan upaya yang mesti di lakukan untuk melakukan perubahan sedangkan belajar itu dapat dikatakan sebagai usaha dan upaya yang mesti dilakukan untuk memperoleh perubahan pada sikap sehari-hari. Model itu sebenarnya dapat di katakan sebagai kegiatan yang terjadi pada semua jenis kegiatan. Model juga dapat dikatakan sebagai kegiatan yang terjadi pada semua orang tanpa mengenal batas usia, dan berlangsung seumur hidup. Belajar juga dapat membawa suatu perubahan padaindividu yang belajar. Sementara itu menurut teori konstruktivisme menyatakan bahwa teori belajar adalah kegiatan yang aktif dimana subyek didik belajar membangun sendiri pengetahuannya, dan mencari sendiri makna sesuatu yang dipelajari. Selanjutnya dikatakan bahwa Sebuah model merupakan gambaran mental yang membantu kita untuk menjelaskan sesuatu dengan lebih jelas

\footnotetext{
3 .Anni, Ibid,2007,hal.10.

4 .Anni, Ibid,2007.hal.4
}

terhadap sesuatu yang tidak dapat dilihat atau tidak dialami secara langsung.

Pembelajaran kreatif dan produktif adalah model yang dikembangkan dengan mengacu kepada berbagai pendekatan pembelajaran yang diasumsikan mampu meningkatkan kualitas proses dengan cara mampu mengkontruksikan konsep dan materi belajar. Pembelajaran ini berpijak kepada teori konstruktivistik dimana belajar adalah usaha pemberian makna oleh peserta didik kepada pengalamannya, dengan demikian dalam pembelajaran ini para peserta didik diharapkan dapat mengkonstruksi sendiri konsep atau materi yang mereka dapatkan. Pendekatan pembelajaran kreatif produktif antara lain : belajar aktif, kreatif, konstruktif serta kolaboratif dan kooperatif. Karakteristik penting dari setiap pendekatan tersebut diintegrasikan sehingga menghasilkan satu model yang memungkinkan peserta didik mengembangkan kreativitas untuk menghasilkan produk yang bersumber dari pemahaman mereka terhadap konsep yang sedang dikaji.

Pembelajaran kreatif produktif ini berlandaskan pada prinsip-prinsip dasar

1. Keterlibatan peserta secara intelektual dan emosional dalam pembelajaran

2. Peserta didik didorong untuk menemukan / mengkonstruksi 
NUSANTARA : Jurnal Ilmu Pengetahuan Sosial - Vol. 6 No 1 (2019) ( Januari - Juni )

issn online : $2550-0813$ issn cetak : $2541-657 \mathrm{X}$

http://jurnal.um-tapsel.ac.id/index.php/nusantara

sendiri konsep yang sedang dikaji melalui penafsiran yang dilakukan dengan berbagai cara seperti observasi, diskusi, atau percobaan

3. Memberi kesempatan kepada peserta didik untuk bertanggung jawab menyelesaikan tugas bersama

4. Untuk menjadi kreatif, seseorang harus bekerja keras, berdedikasi tinggi, antusias serta percaya diri

Dengan mengacu pada karakteristik tersebut, model pembelajaran ini dapat diterapkan dalam pembelajaran berbagai bidang studi, baik topik-topik yang bersifat abstrak maupun yang bersifat konkret. Materi yang sesuai dengan model pembelajaran tersebut merupakan materi yang menuntut pemahaman yang tinggi terhadap nilai, konsep atau masalah actual di masyarakat serta keterampilan menerapkan pemahaman tersebut dalam bentuk karya nyata dari IPS, masalah polusi dari IPA dan lain sebagainya.

\section{Tipe/Jenis Penelitian yang Digunakan}

Tipe ataupun Jenis penelitian ini adalah penelitian Komparatif. Menurut Sugiyono bahwa: "Penelitian Komparatif adalah penelitian yang bertujuan untuk mengetahui hubungan antara duavariabel atau lebih." 5

\footnotetext{
${ }^{5}$ Sugiono, Metode Penelitian Pendidikan, Bandung: Alfabeta 2010, hal. 57
}

Penelitian Komparatif yakni untuk membandingkan dan mencari gambaran tentang ketiga variabel, serta melihat hubungan antara tiga variabel tersebut, dengan pendekatan korelasional yaitu Model Pembelajaran Kreatif sebagai variabel $\mathrm{X}_{1}$,dan Model pembelajaran Produktif sebagai variabel $\mathrm{X}_{2}$,Minat belajar Peserta didiksebagai variabel $\mathrm{Y}$.

\section{Pembahasan}

Dari perhitungan t-test polled varians tersebut maka t-hitungnya adalah 6,667 dengan melihat daftar ttabel dengan jumlah sampel 60 kemudian digunakan derajat kebebasan (dk) $\mathrm{ni}+$ $\mathrm{n}_{2}-2$ dan taraf kesalahan 5\% adalah Sesuai dengan ketentuan jika $t_{\text {hitung }}>t_{\text {tabel }}$ dengan kata lain $(6,667<2000)$ maka hipotesis alternatif (Ho) dapat diterima.

Dari perhitungan di atas, maka hipotesis alternative (Ho) menyatakan: "Ada perbandingan model pembelajaran kreatif dengan model pembelajaranproduktif pada bidang studi PPKn di kelas X SMA Negeri 1 Ulu Barumun Tahun Pelajaran 20162017 "Setelah dilakukan pengujian hipotesis diperoleh $\quad t_{\text {hitung }}=6,667$ sedangkan nilai $t_{\text {tabel }}=2000$, ini menunjukkan $t_{\text {hitung }}>t_{\text {tabel, }}$, artinya ada perbandingan diantara model pembelajaran kreatif dengan model pembelajaranproduktif pada bidang studi PPKn di kelas X SMA Negeri 1 Ulu Barumun Tahun Pelajaran 2016-2017.

\begin{tabular}{lcr}
\multicolumn{2}{c}{ Berdasarkan } & hasil yang \\
diperoleh & bahwa & penelitian \\
menunjukkan & ada & penbandingan
\end{tabular}


NUSANTARA : Jurnal Ilmu Pengetahuan Sosial - Vol. 6 No 1 (2019) ( Januari - Juni )

issn online : $2550-0813$ issn cetak : $2541-657 \mathrm{X}$

http://jurnal.um-tapsel.ac.id/index.php/nusantara

pembelajaran kreatif dengan produktif sesuai dengan perhitungan yang dilakukan. Sehingga penulis berasumsi bahwa dengan melakukan berbagai model pembelajaran bisa menunjukkan suatu dan minat belajar peserta didik dalam menerima pembelajaran di dalam suatu kelas apalagi mata pelajaran khususnya PPKn.

\section{Kesimpulan}

Berdasarkan hasil analisa yang dilakukan dengan pengujian hipotesa bahwa dalam pembelajarandengan modelkreatif dengan produktif terhadap minat belajar pada bidang studi PPKn dapat disimpulkan sebagai berikut:

1. Data yang diperoleh dengan teknik analisa data dengan menggunakan rumus $t$ test polled varians. Setelah dilakukan analisa data maka $t_{\text {hitung nya }}$ adalah6,667dengan melihat daftar $t_{\text {tabel }}$ dengan jumlah sampel 60 dengan derajat kebebasan (dk) $\mathrm{n}_{1}+$ $\mathrm{n}_{2}-2$ dan taraf kesalahan $5 \%$ adalah 2000 dengan demikian dapat diketahui $t_{\text {hitung }}$ lebih besar dan $t_{\text {tabel }}$ yaitu 6,667< 2000 maka hipotesis alternatif (Ho) dapat diterima.

2. Perbandingan antara model pembelajaran kreatif dengan pembelajaranproduktif tenhadap minat belajar peserta didik pada bidang studi PPKn di kelas XSMA Negeri 1 Ulu Barumun Tahun Pelajaran 2016-2017 diperoleh thitung $=6,667$ dan $t_{\text {tabel }}=2000$, karena penulis berpatokan pada ketentuan jika $t_{\text {hitung }}>t_{\text {tabel }}$ maka Ha ditolak dan $\mathrm{H}_{0}$ diterima, karena $\mathrm{t}_{\text {hitung }}<\mathrm{t}_{\text {tabel }}$ $6,667<2000$. Jadi kesimpulan ada perbandingan antara kedua variabel tersebut karena Ha ditolak dan Ho diterima.

Dengan terkumpulnya data-data dalam penelitian ini yang diperoleh dari peserta didik di kelas X SMA Negeri 1 Ulu Barumun Tahun Pelajaran 20162017, dengan penyebaran angket. Setelah data terkumpul kemudianpenulis mengadakan analisa dengan rumus t-test polled varians.

Berdasarkan perhitungan tersebut dapat disimpulkan bahwa hipotesis yang penulis ajukan dapat diterima dan benar kebenanannya dalam perbandingan antara pembelajarankreatif dengan produktif terhadap minat belajar peserta didik pada bidang studi PPKn

\section{DAFTAR PUSTAKA}

Azwar, Syaifuddin, 2010, Metode Penelitian. Yogyakarta,Pustaka Pelajar.

Ali, Muhammad,2007, Penelitian Pendidikan dan Strategi,Bandung Tarsito.

A.M. Sardiman, 2009.Interaksi dan Motivasi Belajar Mengajar, Jakarta :Raja

Grafindo Persada.

Arikunto, Suharsimi, 2008, Metodologi Penelitian Sosial Ekonmi Yogyakarta 
NUSANTARA : Jurnal Ilmu Pengetahuan Sosial - Vol. 6 No 1 (2019) ( Januari - Juni )

issn online : $2550-0813$ issn cetak : 2541-657X

http://jurnal.um-tapsel.ac.id/index.php/nusantara

CV.Andi

Arikunto, Suharsimi, 2006, Pengantar

Prosedur penelitian Suatu Pendekatan

Praktik Jakarta Bumi Aksara.

------------, 2006,

Manajemen Penelitian ,Jakarta:Rineka Cipta.

Anwar, Dessy, 2006, Kamus Lengkap

Bahasa Indonesia.Penerbit Surabaya

Anni, 2006, Psikologi Belajar, Semarang,UPT UNNES,Press.

B. Uno, Hamzah. 2006, Perencanaan

Pembelajaran, Jakarta.Bumi Aksara.

Burhan Bungin, 2011, Metodologi

Penelitian Kuantitatif,Jakarta,Kencana.

Darsono, 2006, Belajar dan

Pembelajaran, Semarang, IKIP.

Djaali, 2009, Psikologi Penedidikan, Jakarta: Bumi Aksara.

--------, 2013, Ensiklopedi Pendidikan.

Jakarta.

Hamdani ， 2006, Model- model

Pembelajaran,Jakarta.Bumi Aksara.

Hamdani, 2011, Strategi Belajar

Mengajar, Bandung, CV. Pustaka

Setia.

Hamalik,Oemar, 2006, Kurikulum dan

Pengajaran, Bandung: Bumi Aksara.

Nazir, Muhammad, 2006, Metode Penelitian.Jakarta :PT Rineka Cipta.

Mudhofir, 2009, Kamus Etika, Jakarta

: Pustaka Pelajar.

Mardiyatmo, 2007, Ekonomi Bandung

: Yudhistira.

S. Jujun. 2006, .Prosedur Penelitian, Jakarta.Tarsito.

Sutisna, 2007, Ekonomi Bandung : Yudhistira.
Sudarsono,2008, Pengantar teori

Ekonomi bandung : Yudhistira.

Sudjana, Nana,2009, Cara Belajar

Siswa Aktif dalam Proses Belajar

Mengajar,

Bandung Sinar Baru.

Sudjana, Nana , 2006,Dasar- dasar

Proses

Belajar

Mengajar,Bandung,Sinar Baru

Alegensindo.

Sudjana, 2008, Metodologi Penelitian

Pendidikan, Jakarta: Bumi Aksara.

Sutikno, Sobry, 2010, Strategi Belajar

Mengajar,konsep umum dan islami

Jakarta Refika Aditama.

Sanjaya, Wina, 2006, Strategi

Pembelajaran Berorientasi Standar

Proses

Pendidikan Jakarta Kencana

Prenada Media Group.

Slameto, 2010, Belajar dan Faktor-

Faktor yang Mempengaruhinya, Jakarta:

Rineka Cipta.

Informasiku.Com, Jakarta.

Sardiman, 2006, Strategi Belajar Mengajar, Surabaya: Usaha Nasional.

Supiah, 2007, Managemen Pendidikan , Jakarta : Penerbit Andi Offset.

Sugiyono, 2006, Metode Penelitian Administrasi,Bandung ,Alfabeta.

Kamus besar Bahasa Indonesia, 2006, Defenisi Belajar, Jakarta.PT.Rineka Cipta.

Istarani, 2012, 58 model Pembelajaran Inovatif,Media Persada ,Medan.

Treffinger, 2011, pengembangan kreativitas anak, Jakarta. 
NUSANTARA : Jurnal Ilmu Pengetahuan Sosial - Vol. 6 No 1 (2019) ( Januari - Juni ) issn online : $2550-0813$ issn cetak : $2541-657 \mathrm{X}$

http://jurnal.um-tapsel.ac.id/index.php/nusantara

Trianto. 2009, Mendesain Model

Pembelajaran Inovatif-Progresif

Surabaya

Kencana Prenada media Group.

Trianto, 2007, Model Pembelajaran

Terpadu dalam Teori dan Praktik,

Jakarta :

Prestasi Pustaka.

Walgito, 2005, Pengelolaan Kelas

Belajar, Yogayakarta: AN Offset. 